\title{
市政道路设计的实践研究
}

\author{
吕涁 \\ 华汇工程设计集团股份有限公司上虞交通市政分院 \\ DOI:10.32629/btr.v2i8.2470
}

[摘 要] 随着社会经济的快速发展,城市市政公共部门对基础设施的建设投入也在不断增加,为了能够让这些基础设施更加 符合人们的日常生活要求,需要保证设计理念增加实践环节。本文对我国城市市政道路设计存在的问题进行实践,并展开研究。 [关键词] 市政道路; 设计方法; 研究

随着我国经济的高速发展, 社会生产和居民生活对交通 业提出了更高的要求, 作为交通业重要组成部分的城市市政 道路直接关系着城市交通运输能力的高低。城市市政道路不 仅具有运输的作用, 同时也是一个城市的形象和发展水平的 表现。在我国, 部分城市的市政道路设计和规划缺乏科学合 理性, 阻碍了城市经济和城市规划的进一步发展。

\section{1 城市市政道路设计实施中的必要性}

为了缓解现代城市交通压力, 城市道路设计部门应借助 城市改造与新城区建设发展的机会开展道路设计与改造, 以 此实现缓解城市交通压力的目的。在城市发展以及城市建设 工作中, 城市道路不仅与城市居民的日常生活息息相关, 更 是整个城市经济发展的核心环节。城市道路是城市的重要组 成部分, 也是城市基础建设的核心环节, 通常来说, 在城市道 路设计工作中, 由于城市道路本身就属于市政交通的一种, 因此在设计中通常都是从公共设施的角度去分析和总结, 不 仅仅只是关注到它的使用功能上的发挥, 还要对它的艺术效 果、使用效果加以总结及完善。

\section{2 我国城市市政道路设计实践中存在的问题}

2.1道路结构缺乏合理性

部分城市的道路在设计之初局限于城市道路眼前发展 的需要, 忽视了整个城市道路网络化的要求发展, 设计出的 作品阻碍了城市道路网络结构合理化的发展, 导致市政道路 交通功能的紊乱。

\section{2 道路交通要点通畅性差}

在道路设计之前应该对道路的交通情况进行分析, 主要 包括交通流量和方向、道路周边路网的交通情况以及车辆的 组成和车速等, 设计者对道路交通情况的不了解导致设计出 的道路在车道数、路段以及交叉口的设计缺乏科学依据, 致 使道路网点交通压力过大, 制约了交通的通畅。

\section{3道路横断面设计缺乏科学性}

由于在道路设计中忽视了道路设计规划性, 导致了道路 横断面设计缺乏科学性, 主要表现在以下几个方面。一、对 道路交通情况和道路通行能力没有进行定量、定性的分析。 二、道路交通功能不明确。三、设计工作主要套用设计规范, 没有结合具体道路的具体情况。四、对于道路周边的绿化带、 站台、隔离带以及环保方面的考虑不充分。
2. 4无法满足特殊人员出行的要求

作为城市居民组成部分的特殊人员, 道路设计者在道路 设计过程中没有重视特殊人员出行的要求, 出现了盲道少且 使用不到的现象, 盲道设计不合理无法为特殊人员提供正确 的方向指示, 无法满足特殊人员出行的需求。

\section{3 城市市政道路设计的思想}

3. 1道路设计要与城市特点保持一致

随着经济全球化程度的不断加深, 许多城市丧失了自身 原有的特色。经济的发展不仅提高了人们对物质生活的要求, 也提高了精神文化的追求, 越来越多的人们开始关注自身所 在城市的个性发展。因此市政道路设计人员在设计道路过程, 首先要了解该城市历史、文化等特色, 同时把握好城市未来 发展的方向, 依据城市的个性和特点设计出符合城市发展要 求和城市未来形象的方案, 在城市的地理环境和原有道路有 利条件的基础上进行, 这样既可突出城市地方特色, 又可以 降低市政道路工程成本。

3. 2 强化城市道路功能

市政道路除了要满足交通需求外, 更要体现出道路的生 活功能和美化功能以及旅游功能等。例如: 我国某城市的交 通干道深南路的延伸路段深南大道经相关部门的认真规划 以及大力建设后已经成为该城市最主要的旅游交通干道, 这 不仅强化了道路的功能, 同时提高了市政道路的经济价值。 我国市政道路从功能上一般分为生活性、交通性、商业性和 景观性道路。其中交通性道路主要是为了满足城市交通的需 要和建设的, 因此交通性道路车流量大, 所以要求道路路面 宽且车道数量较多, 因此这类道路设计中要突出机动车车道, 设置两幅路, 非机动车道与人行道规格可放低。生活性的道 路主要是用来满足城市居民生活的需求, 如购物、娱乐等, 一般路上行人较多, 上下班是人流高峰期, 所以在该类道路 的设计要以满足居民的出行要求为主, 实行公交先行的原则, 划分公交专用车道, 同时划分机动车道和非机动车道, 并设 置合理的人行横道方便行人过街。商业性的道路特点在于周 边有大量的餐饮、娱乐、购物等场所, 所以要求道路的通达 性好, 因此在道路设计过程中提高人行道路空间。景观性道 路是城市发展旅游的重要交通枢纽, 因此道路两边必须强化 景观设计, 人行道空间较大, 满足行人休媳与观赏的需要, 同 
时保留自行车道。

\section{4 城市市政道路设计实践方法}

4. 1 交通性道路的设计方法

交通性道路的设施服务对象是车行交通，因此人行天 桥、路灯、护栏以及候车亭的设计要以简约明快风格为主, 突出这些设施的实用性即可。同时交通标志和标线的设置中 要注意在交通标志位置的前方留足提前量, 方便机动车驾驶 员在行使过程中提前了解路况, 做好心理准备, 这样有利于 减少交通事故的发生, 提高交通的流畅性。

4. 2 生活性道路和商业性道路的设计方法

城市生活性道路主要以街道的形式体现, 这类道路的交 通情况较为复杂, 表现为人车混合性, 因此对道路设计工作 要求更高。设计人员在进行设计前必须对道路的交通情况进 行详细的了解, 同时尽可能的多设计交通标志。由于生活性 街道对停车的需求大, 所以在道路设计中要重视停车位的设 置, 满足各类车型车辆的停靠需求。同时在道路设计中充分 利用引导和限制手段, 保证交通的流畅, 如限速等, 以此增加 市民活动的空间, 提高市民生活的方便度。具体措施如下。 一、将道路的平面线形设计成蛇形状或锯齿状, 这样做可以 促使进入该道路的车辆减速, 同时由于道路线路的曲折性降 低了外来车辆进入该种车道的倾向, 从而减少了车流量, 而 且曲线性的道路在观赏性和趣味性方面更符合人们的需求。 二、在道路中央或两边种植相应的树木。这样做可以减少外 来车辆进入车道的想法, 同时能够改善道路的环境, 达到美 化城市的目的。三、在道路交叉口有意识的将道路设计成凹 凸状, 通过道路路面的提高或降低, 给车辆驾驶员在行驶过 程中制造震动感, 从而促使驾驶员减速。另外可以间接性的 缩短道路的宽度, 在保证车辆能够通行的情况下给驾驶员不 易通过的感觉, 从而达到控制车流的目的。四、在市民居住 区的道路设计上除了要在交叉口设置相应的交通标志, 要求
驾驶减速或转弯外, 还要坚持以人为本的原则, 实现道路网 络的灵活化和活泼化, 满足居民舒适生活的要求。

\section{3 景观性道路的设计方法}

景观性道路在很大程度上反应了城市的文化特征和精 神面貌。同时也反应了一个城市的绿化水平, 因此景观性的 道路在设计时应该根据城市整体发展的要求进行规划和设 计。如在景观性道路旁边有广场时, 从道路进入广场的路口 要保证充足的空间, 提高进入路口舒适感, 同时增加路口的 绿化效应, 实现路口与广场景色的一致性, 另外景观性道路 两旁的植物和树木在选择上要满足观赏性的需求, 实现多样 化和丰富化。

\section{5 结束语}

城市市政道路设计的通畅与否对整个城市的建设规划 有直接的影响, 因此, 应该加强城市道路设计工作。尤其近年 来随着我国的经济以及城市化建设的快速推进, 方便了城市 居民的出行, 也产生了许多新的矛盾和问题, 加大了城市道 路设计的复杂性, 对道路设计工作提出了更高的要求, 因此在 道路规划及设计中要求我们进行全面的思考和总结。对研究 城市市政道路设计的实践方法与思想具有重要的现实意义。

\section{[参考文献]}

[1]杜相儒.关于市政道路单向交通设计思路和优缺点 探析[J].山西建筑,2018,44(33):105-106.

[2]何冬英.浅谈市政道路设计的新思考 [J].中国电子商 务,2010,(8):349.

[3]何伟.道路设计思路与技术要点 [J]. 黑龙江交通科 技,2013,(8):12.

[4]张林志.市政道路存在的问题与规划改进设计分析 [J].民营科技,2011,(09):277.

[5]席永红.浅谈市政道路的无障碍设计 [J].黑龙江交通 科技,2011,34(4):13. 